\title{
Effects of antineoplastic phospholipids on parameters of cell differentiation in U937 cells *, **
}

\author{
Christa Hochhuth $^{1}$, Dinko Berkovic ${ }^{2}$, Hansjörg Eibl ${ }^{3}$, Clemens Unger ${ }^{2}$, and Detlef Doenecke ${ }^{1}$ \\ 1 Institut für Biochemie, Abteilung Molekularbiologic \\ ${ }^{2}$ Universitätsklinikum, Abteilung Hämatologie/Onkologie, and \\ 3 Max-Planck-Institut für Biophysikalische Chemie, D-3400 Göttingen, Federal Republic of Germany
}

Received 18 June 1990/Accepted 25 June 1990

\begin{abstract}
Summary. The proliferation of the human promonocytic leukemia cell line U937 is inhibited by several ether lipids, ether lipid analogues and by phorbol esters. An early effect of this retardation of cell growth is the induction of a basic chromosomal protein, histone $\mathrm{H}^{0}$. Northern blot analysis of $\mathrm{H} 1^{\circ} \mathrm{mRNA}$ levels reveals an increase of the mRNA concentration within a few hours after addition of hexadecylphosphocholine and 1-O-octadecyl-2-Omethyl-rac-glycero-3-phosphocholine. This early effect on the synthesis of a subtype of $\mathrm{H} 1$ proteins precedes the expression of several parameters of the monocytic differentiation of U937 cells.
\end{abstract}

Key words: Antineoplastic phospholipids - U937 cells cell differentiation - histone $\mathrm{H} 10$

\section{Introduction}

The alkyllysophospholipid 1-O-octadecyl-2-O-methylrac-glycero-3-phosphocholine $\left(\mathrm{ET}-18-\mathrm{OCH}_{3}\right)$ and the alkylphosphocholine hexadecylphosphocholine (He-PC) show a variety of biological properties. Besides activation of macrophages (Munder et al. 1976) and modulation of interleukin-1 and -2 secretion by lymphocytes (Andreesen et al. 1987) these compounds possess pronounced

\footnotetext{
* Dedicated to Professor Dr. D. Schmähl on the occasion of his 65 th birthday

** Supported by the Deutsche Forschungsgemeinschaft (D.D.) and the Ministry for Research and Technology (C.U.)

Abbreviations: ES-16-OH, 1-O-palmitoyl-sn-glycero-3-phosphocholine, ET-18- $\mathrm{OCH}_{3}$, 1-O-octadecyl-2-O-methyl-rac-glycero-3phosphocholine; He-PC, hexadecylphosphocholine; TPA, 12-Otetraclecanoylphorbol 13-acetate; $\mathrm{He}_{-} \mathrm{PC}_{6}$, hexadecylphospho( $N, N, N$-trimethylamino)-hexanol

Offprint requests to: $\mathrm{C}$. Hochhuth, Medizinische Univ.-Klinik, Abt. Hämatologie/Onkologie, Robert-Koch-Str. 40, D-3400 Göttingen, FRG
}

dose-dependent antiproliferative activity in vitro and in vivo (Berdel et al. 1981; Munder et al. 1981; Vehmeyer et al. 1989; Muschiol et al. 1987; Hilgard et al. 1988). Moreover, these compounds can induce differentiation of leukemic cell lines into mature myeloid cells (Honma et al. 1981, 1983; Hilgard et al. 1989), and some data suggest that induction of differentiation may contribute to the in vivo antitumoral activity of He-PC in chemically induced rat mammary carcinomas (Hilgard et al. 1988). The interaction and incorporation of these compounds within the cell membrane finally result in biological effects on several cellular processes, leading to an inhibition of DNA replication.

An arrest of DNA synthesis is frequently accompanied by changes of the pattern of chromosomal proteins (D'Anna et al. 1982; D'Incalci et al. 1986). Non-dividing, terminally differentiated cells, such as hepatocytes (Panyim and Chalkley 1969; Gabrielli et al. 1985; Gjerset et al. 1982) or nerve cells (Pina and Suau 1987; Pina et al. 1984) show an increased level of the H1 histone subtype $\mathrm{H} 1^{\circ}$. Unlike other histones, the synthesis of this subtype does not depend on DNA replication (Zlatanova 1980), and it has been demonstrated in a variety of systems that several inhibitors of cell growth induce the de novo synthesis of this chromosomal protein (Zlatanova 1980; Chabanas et al. 1985; Pehrson and Cole 1980; Hall et al. 1985; Pieler et al. 1981).

This correlation led to the initial suggestion that the presence of $\mathrm{H} 1^{\circ}$ may be either a prerequisite or a consequence of an inhibition of DNA replication (van Helden 1985). Induction of differentiation, however, has shown in several in vitro systems a de novo synthesis of $\mathrm{H} 1^{\circ}$ despite a continued DNA synthesis in these cultured cells (Alonso et al. 1988; Keppel et al. 1977).

In this communication, we describe the kinetics of $\mathrm{H} 1^{\circ}$ mRNA accumulation in the human promonocytic leukemia cell line U937 after addition of the alkyllysophospholipid ET-18-OCH 3 and the alkylphosphocholine He-PC. We demonstrate that the early effect on $\mathrm{H} 1^{\circ}$ mRNA induction precedes an increase of markers of a monocytic differentiation. 


\section{Materials and methods}

Materials. Cell-culture materials were from Gibco/BRL (Gaithersburg Md.), enzymes were from Boehringer (Mannheim), chemicals for electrophoresis were from Serva (Heidelberg) denaturing agents were purchased from Fluka (Buchs, Switzerland). Other chemicals were from Merck (Darmstadt). Blotting membranes were from Amersham (Braunschweig) and Schleicher and Schüll (Dassel). Anti HLA-DR, Leu3, LeuM3 and anti-(transferrin receptor) monoclonal antibodies were obtained from Becton Dickinson (Heidelberg). MO1 and MO2 monoclonal antibodies were from Coulter (Krefeld). Nitroblue tetrazolium and 12-O-tetradecanoylphorbol 13acetate (TPA) were purchased from Sigma (München).

Ether phospholipids and phospholipid analogues. 1-O-Palmitoyl-snglycero-3-phosphocholine (ES-16-OH), 1-O-octadecyl-2-O-methylrac-glycero-3-phosphocholine (ET-18- $\mathrm{OCH}_{3}$ ), hexadecylphosphocholine (He-PC) and hexadecylphospho- $(N, N, N$-trimethylamino)hexanol $\left(\mathrm{He}_{\mathrm{PC}}\right)$ were synthesized as previously described (Eibl 1981). The chemical structures of the different compounds are given in Fig. 1. The substances were dissolved in methanol/chloroform, dried under nitrogen and redissolved in serum-free RPMI-1640 medium. These stock solutions were sonicated for 10 min just before use.

Phorbol ester (TPA) was dissolved in RPMI-1640 medium as a stock solution and was added to the cell culture (final concentration $32 \mathrm{n} M$ ).

Cell culture. Human promonocytic leukemia U937 cells were continuously cultured in RPMI-1640 medium, supplemented with $10 \%$ fetal calf serum, penicillin/streptomycin $(100$ units $/ \mathrm{ml}$ and $100 \mu \mathrm{g} /$ $\mathrm{ml}$, respectively) and glutamine $(2 \mathrm{mM})$ at $37^{\circ} \mathrm{C}, 5 \% \mathrm{CO}_{2}$. Cells were seeded at a density of $2 \times 10^{5}$ cells $/ \mathrm{ml}$ and incubated in the presence or absence of test substances for different periods of time.

ES-16- OH

$$
\begin{aligned}
& \mathrm{O} \\
& \mathrm{H}_{2} \mathrm{C}-\mathrm{O}-\stackrel{\mathrm{C}}{\mathrm{C}}-(\mathrm{CH})_{14}-\mathrm{CH}_{3} \\
& \mathrm{HC}-\mathrm{OH} \\
& \mathrm{I} \\
& \mathrm{I}_{2} \mathrm{C}-\mathrm{O}-\mathrm{O}-\mathrm{O}-\mathrm{CH}_{2}-\mathrm{CH}_{2}-\stackrel{+}{\mathrm{N}}\left(\mathrm{CH}_{3}\right)_{3} \\
& \mathrm{O}^{-}
\end{aligned}
$$

ET-18- $-\mathrm{OCH}_{3}$

$$
\begin{gathered}
\mathrm{H}_{2} \mathrm{C}-\mathrm{O}-\left(\mathrm{CH}_{2}\right)_{17}-\mathrm{CH}_{3} \\
\mathrm{H}_{3} \mathrm{C}-\mathrm{O}-\mathrm{CH} \\
\mathrm{CH}_{2}^{\mathrm{O}} \\
\mathrm{H}_{2} \mathrm{C}-\mathrm{O}-\ddot{\mathrm{P}}-\mathrm{O}-\mathrm{CH}_{2}-\mathrm{CH}_{2}-\mathrm{N}\left(\mathrm{CH}_{3}\right)_{3} \\
\mathrm{O}^{-}
\end{gathered}
$$

He-PC

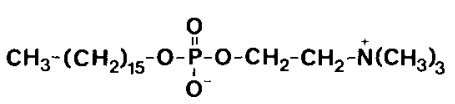

$$
\begin{aligned}
& \mathrm{He}-\mathrm{PC}_{6}
\end{aligned}
$$

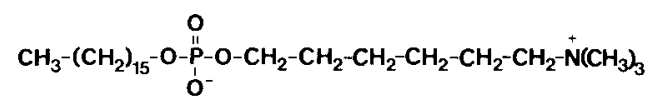

Fig. 1. Chemical structures of phospholipids and phospholipid analogues
Cells were then collected and washed in fresh medium. Cell number and viability was determined in a Neubauer chamber by trypan blue dye exclusion.

$R N A$ analysis. Cells were washed twice in ice-cold phosphate-buffered saline $\left(0.14 M \mathrm{NaCl}, 2.5 \mathrm{~m} M \mathrm{KCl}, 8.1 \mathrm{~m} M \mathrm{Na}_{2} \mathrm{HPO}_{4}, 1.5 \mathrm{~m} M\right.$ $\mathrm{KH}_{2} \mathrm{PO}_{4}$, pH 7.4) and total cellular RNA was prepared by the guanidinium isothiocynate/ $\mathrm{CsCl}$ method (Chirgwin et al. 1979). Cell homogenates in lysis buffer [4 $\mathrm{M}$ guanidinium isothiocyanate, $0.5 \%$ (w/v) $N$-lauroylsarcosine, $25 \mathrm{mM}$ sodium citrate, $0.1 M$ 2-mercaptoethanol] were centrifuged in a Beckman SW60 rotor for $16 \mathrm{~h}$ at $180000 \mathrm{~g}\left(15^{\circ}\right)$. The RNA sediment was dissolved in sodium dodecyl sulfate buffer [ $10 \mathrm{~m} M$ TRIS/HCl, pH 7.2, $5 \mathrm{~m} M$ EDTA, $1 \%(\mathrm{w} / \mathrm{v})$ sodium dodecyl sulfate], precipitated with ethanol, washed several times with $80 \%$ ethanol, dried and dissolved in water. Samples of $10 \mu \mathrm{g}$ RNA were denatured in glyoxal $(5 \%, \mathrm{v} / \mathrm{v})$ and dimethylsulfoxide $(50 \%, \mathrm{v} / \mathrm{v})$ for $1 \mathrm{~h}$ at $50^{\circ} \mathrm{C}$ (McMaster and Carmichael 1977). Denatured RNA was electrophoretically separated on 1\% agarose gels, transferred onto nylon membranes (Amersham Hybond $\mathrm{N}$ ) and hybridized with labeled DNA probes as previously described (Kress et al. 1986). Endogenous ribosomal RNA could be used as a marker, since human $\mathrm{H}^{\circ}$ mRNA, being about $2.3 \mathrm{~kb}$ in length (Doenecke and Tönjes 1986), has a size intermediate between 28S and 18S RNA, whereas main-group $\mathrm{H} 1$ measures around $0.7 \mathrm{~kb}$ (Eick et al. 1989). DNA probes were derived from the human $\mathrm{H}^{\circ}$ gene (Doenecke and Tönjes 1986), from two human main-type H1 genes (Eick et al. 1989) and from human core histone genes (Eick and Doenecke, unpublished results). After labeling the DNA fragments by nick translation (Rigby et al. 1977), the probes were used for hybridization.

Analysis of surface antigen expression. Quantification of surface antigen expression by flow cytometry was performed by direct immunofluorescence staining with fluorescein-isothiocyamate(FITC-conjugated monoclonal antibodies against human CD14 (LeuM3, MO2), CD4 (Leu4), CD11 (MO1) and HLA-DR antigen. The transferrin-receptor antigen was quantified by indirect immunofluorescence using a FITC-conjugated goat anti-(mouse Ig) monoclonal antibody.

Nitroblue tetrazolium reduction assay. A sample of $3 \times 10^{6}$ cells were suspended in $1 \mathrm{ml}$ medium. An equal volume of $0.2 \%$ nitroblue tetrazolium dissolved in phosphate-buffered saline was added. After $45 \mathrm{~min}$ of incubation at $37^{\circ} \mathrm{C}$ aliquots were taken and the percentage of cells containing formazan deposits was determined in a Neubauer chamber. The remaining cells were pelleted and lysed by addition of Triton X-100 and sonication. Lysates were pelleted again at $2500 \mathrm{~g}$. Supernatants were analyzed in a Hitachi U-2000 spectrophotometer at $560 \mathrm{~nm}$.

\section{Results}

\section{Effects of phospholipids, alkylphosphocholines and phorbol ester on U937 cell proliferation}

U937 cells are derived from a human promonocytic leukemia (Sundström and Nilsson 1976). They can be induced to differentiate towards monocyte-like cells upon addition of a number of different compounds like phorbol ester (Gidlund et al. 1981), retinoic acid (Ways et al. 1988) interferon $\gamma$ (Ralph et al. 1983), colony-stimulating factors (Geissler et al. 1989) and tumor necrosis factor $\alpha$ (Trinchieri et al. 1986). Typically, these U937 cells cease to proliferate and, being treated with some substances, become attached to culture-vessel walls. 
We have treated U937 cells with TPA, the alkyllysophospholipid ET-18- $\mathrm{OCH}_{3}$, the acyllysophospholipid ES-16-OH and the two alkylphosphocholines He-PC and $\mathrm{He}-\mathrm{PC}_{6}$.

Figure 2 shows the influence of these compounds on U937 cell growth. During an initial phase of $24 \mathrm{~h}$ cell division does not occur. Subsequently, control cells start to divide resulting in a fourfold cell number at $48 \mathrm{~h}$. Cells treated with ET-18-OCH 3 , He-PC and TPA, however, do not proliferate, whereas those treated with ES-16-OH and $\mathrm{He}-\mathrm{PC}_{6}$ show growth characteristics similar to control cells.

\section{Effects of phospholipids, alkylphosphocholines and phorbol ester on $\mathrm{H} 1$ histone gene expression}

The synthesis of the majority of histones is tightly coupled to DNA synthesis. In addition to these replication-dependent histones, a few subtypes are synthesized at a basal rate throughout the cell cycle. One of these replacement histones is the $\mathrm{H} 1$ subtype $\mathrm{H} 1^{\circ}$.

We have analyzed the expression of the human $\mathrm{H} 1^{0}$ (Doenecke and Tönjes 1986) histone gene in comparison with two genes coding for main-type H1 histones (Eick et al. 1989). Human DNA probes coding for these histones had been isolated previously from a human genomic library (Eick et al. 1989). In addition, the mRNA coding for a core histone (H 2 A) was analyzed with the respective human gene probe.

Figure 3 shows Northern blots of RNA samples obtained from U937 cells, which had been treated for different periods of time with He-PC. The steady-state levels of

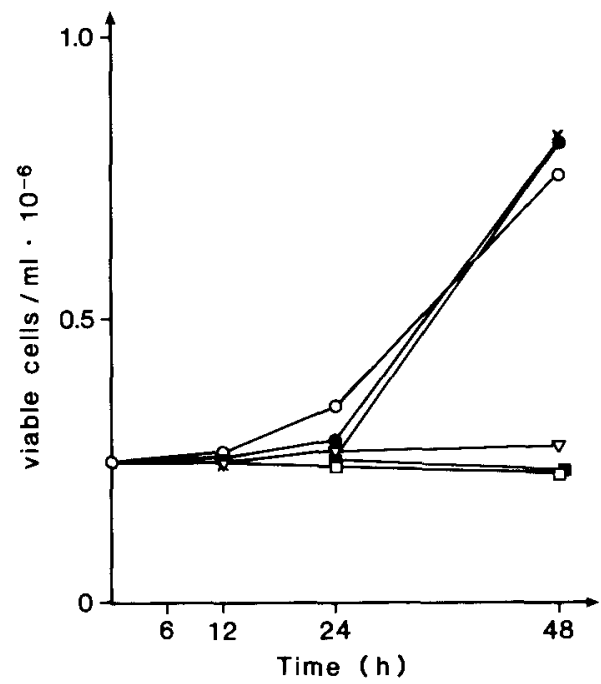

Fig. 2. Effects of varied phospholipids, phospholipid analogues and phorbol ester on growth kinetics of U937 cells: 1-O-octadecyl-2-Omethyl-rac-glycero-3-phosphocholine (ET-18-OCH ${ }_{3}$ () $5 \mu \mathrm{g} / \mathrm{ml}$, hexadecylphosphocholine (He-PC) $(\nabla) 10 \mu \mathrm{g} / \mathrm{ml}$, hexadecylphospho- $\left(N, N, N\right.$-trimethylamino)-hexanol $\left(\mathrm{He}-\mathrm{PC}_{6}\right)(\times) 10 \mu \mathrm{g} / \mathrm{ml}, 1-$ $O$-palmitoyl-sn-glycero-3-phosphocholine (ES-16-OH) (•) $10 \mu \mathrm{g} /$ $\mathrm{ml}$, and 12-O-tetradecanoylphorbol 13-acetate (TPA) (a) $32 \mathrm{nM}$ were added to U937 cells at an initial density of $2 \times 10^{5}$ cells $/ \mathrm{ml}$. The ordinate indicates the number of viable cells $/ \mathrm{ml}$ and the abscissa refers to the time interval after addition of the respective substance (untreated cells: 0 )

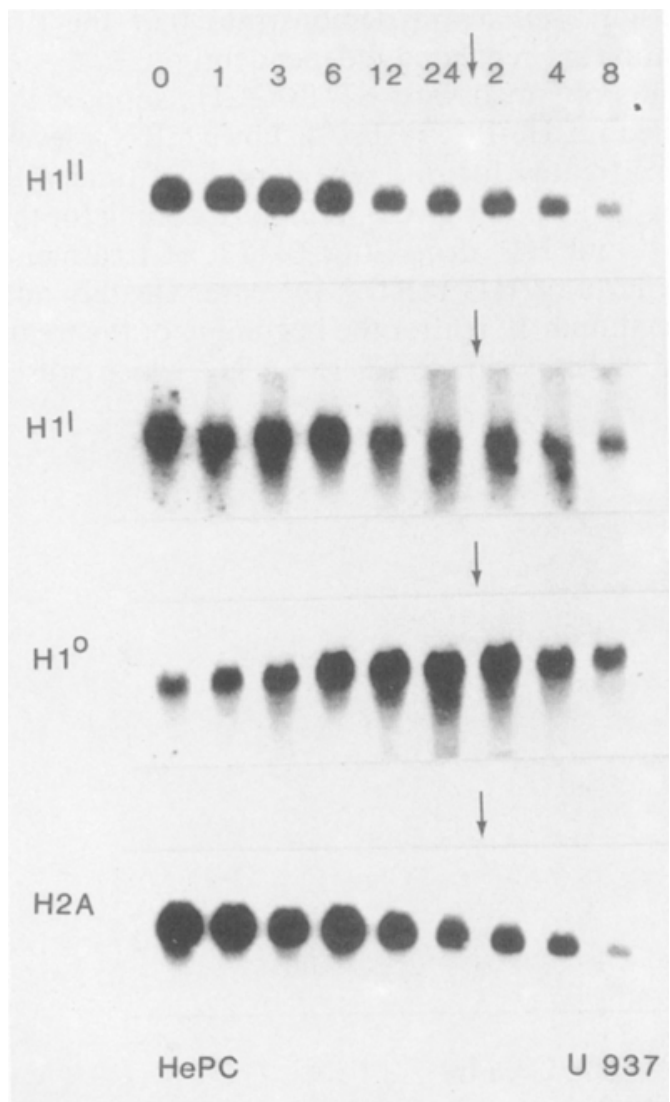

Fig. 3. Steady-state levels of mRNA coding for histone $\mathrm{H} 1^{0}$ and cellcycle-dependent histone species. RNA was extracted at different times (top line, h) after addition of hexadecylphosphocholine $(\mathrm{HePC}, 25 \mu \mathrm{M})$. Identical amounts of RNA $(10 \mu \mathrm{g})$ were separated electrophoretically, blotted and hybridized with ${ }^{32} \mathrm{p}$-labeled probes, derived from genes coding for histone $\mathrm{H} 1^{\circ}$ (Doenecke and Tönjes 1986), two different H1 histones (Eick et al. 1989) and an H2A core histone gene. The vertical arrow indicates removal of He-PC, washing and resuspension of the cells in He-PC-free medium

RNA coding for the replication-dependent histones $\mathrm{H} 1^{\mathrm{I}}$, $\mathrm{H} 1^{\mathrm{II}}$ and $\mathrm{H} 2 \mathrm{~A}$ reflect the growth kinetics as presented in Fig. 2. During the first $6 \mathrm{~h}$ after exposure to $\mathrm{He}-\mathrm{PC}$, the mRNA levels are just marginally reduced. Then the steady-state mRNA concentrations drop and even a removal of the growth-inhibiting compound does not cause a recovery of the expression of these genes within the next $8 \mathrm{~h}$.

In contrast to the replication-dependent $\mathrm{H} 1$ und $\mathrm{H} 2 \mathrm{~A}$ histone genes, the $\mathrm{H} 1{ }^{\circ}$ gene expression is stimulated upon addition of $\mathrm{He}-\mathrm{PC}$ as early as $1 \mathrm{~h}$ after exposure to the compound. The accumulation of the $\mathrm{H} 1^{0}$ mRNA is reversed upon removal of He-PC and nearly reaches the basal level $8 \mathrm{~h}$ after resuspending the cells in control medium.

Thus, we conclude that He-PC affects the synthesis of replication-dependent and replacement histones in opposite directions. Removal of the antineoplastic compound leads to an immediate reversal of the $\mathrm{H} 1^{\circ}$ accumulation, whereas the decrease of the replication-dependent histone mRNA concentration remains unchanged. These kinetics not only describe an He-PC-mediated effect on 
gene expression, but again demonstrate that the two types of histone are regulated independently.

The results obtained with ET-18- $\mathrm{OCH}_{3}$ support the data described for He-PC. Figure 4 shows mRNA levels of U937 cells treated for different periods of time with ET-18-OCH $\mathrm{OCH}_{3}$. Again, the levels of mRNA, coding for the subtypes $\mathrm{H} 1^{1}$ and $\mathrm{H} 1^{1 \mathrm{II}}$ drop after $6-12 \mathrm{~h}$ of treatment, whereas the level of $\mathrm{H} 1^{\circ} \mathrm{mRNA}$ increases steadily and reaches a maximum $12 \mathrm{~h}$ after the beginning of the treatment. Continued exposure to ET-18- $\mathrm{OCH}_{3}$, which causes

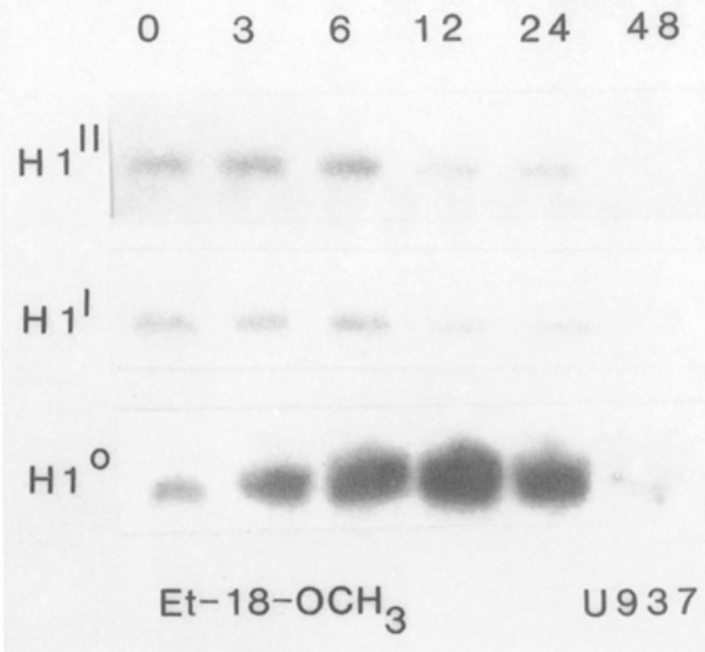

Fig. 4. Levels of mRNA for $\mathrm{H} 1^{\circ}, \mathrm{H} 1^{1}$ and $\mathrm{H}^{11}$ in $\mathrm{U} 937$ cells, which had been exposed for different periods of time (top line, $h$ ) to the alkyllysolecitihin ET-18-OCH $(18 \mu \mathrm{M})$. Identical amounts of RNA were electrophoresed, hybridized with probes coding for human $\mathrm{H} 1$ histones (see above, Fig. 2) and autoradiographed

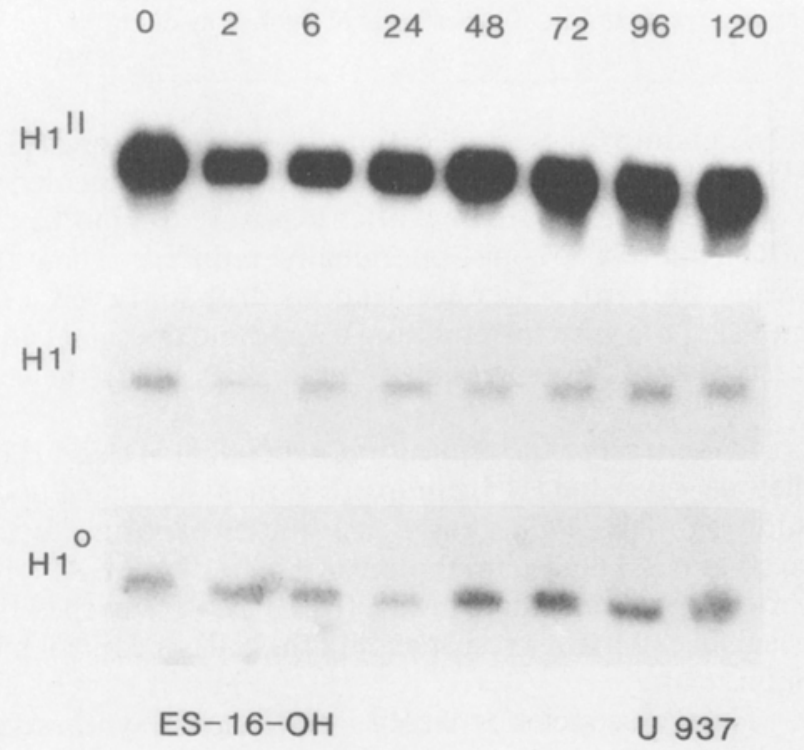

Fig. 5. Levels of mRNA for $\mathrm{H} 1^{\circ}$, $\mathrm{H} 1^{\mathrm{I}}$ and $\mathrm{H} 1^{\mathrm{II}}$ in $\mathrm{U} 937$ cells, exposed for different periods of time (top line, $\mathrm{h}$ ) to the acyllysolecithin ES16-OH. Identical amounts of RNA were electrophoresed, hybridized with the respective probes (see above, Fig. 2) and autoradiographed. The different intensities of the three series are due to different specific activities of the three histone gene probes a decrease of the number of viable cells after $12 \mathrm{~h}$ of treatment, then results in a decrease of the $\mathrm{H} 1^{\circ}$ mRNA.

As shown in Figure 2, ES-16-OH and $\mathrm{He}-\mathrm{PC}_{6}$ do not influence the growth kinetics of U937 cells. This lack of antiproliferative action agrees with the Northern blot results obtained with these substances. Figure 5 summarizes results obtained with one of these compounds, the acyllysophospholipid ES-16-OH. In this case, the levels of the replication-dependent mRNA species $\mathrm{H} 1^{1}$ and $\mathrm{H} 1^{\mathrm{II}}$ drop slightly during the first hours of treatment. After recovery from this initial inhibitory effect, the mRNA concentrations return to their initial levels. The $\mathrm{H} 1^{\circ}$ mRNA steady-state values, on the other hand, vary slightly during the initial hours of ES-16-OH treatment, but the substance elicits neither stimulatory nor inhibitory effects on the $\mathrm{H} 1^{\circ}$ gene expression.

Phorbol ester is known to induce differentiation of U937 towards macrophage-like cells (Gidlund et al. 1981). Figure 2 demonstrates that this is accompanied by an inhibition of cell division. Thus, TPA treatment of U937 cells provides a system to monitor the correlation between inhibition of DNA replication and $\mathrm{H}^{\circ}$ induction. Figure 6 shows that the level of $\mathrm{H} 1^{0} \mathrm{mRNA}$ in-

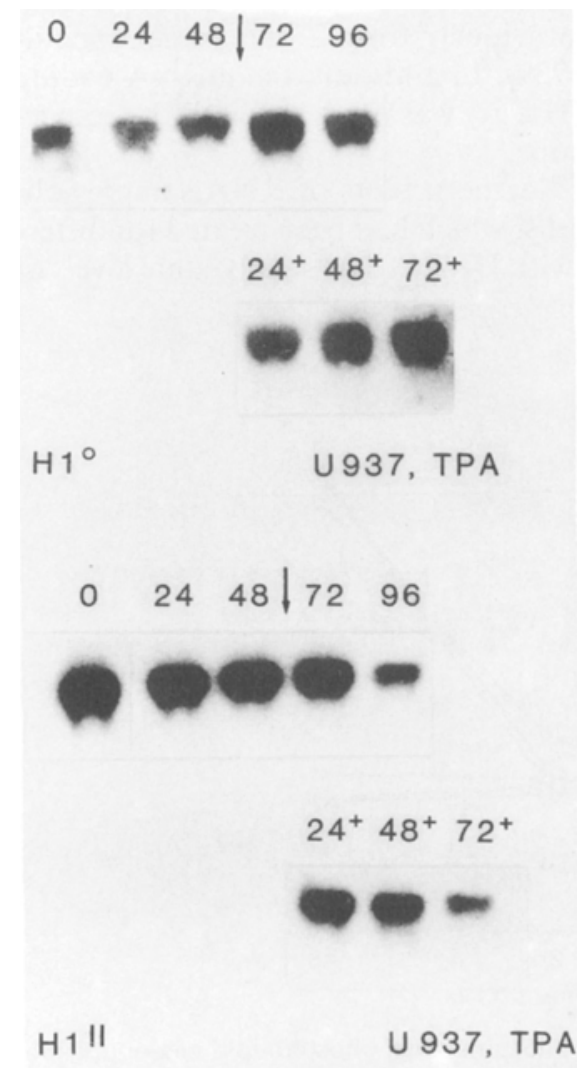

Fig. 6. Effect of TPA ( $32 \mathrm{nM})$ on levels of mRNA coding for $\mathrm{H} 1^{\circ}$ and for the replication-dependent $\mathrm{H} 1$ subtype $\mathrm{H} 1^{\mathrm{II}}$. Each lane represents identical amounts of RNA, extracted from U937 cells after the periods of TPA treatment indicated $(\mathrm{h})$ above each series. At the time indicated by a vertical arrow, part of the cell suspension was washed and resuspended in TPA-free medium, and RNA was extracted from cells at different intervals thereafter $\left(\mathrm{h},{ }^{+}\right)$. The other part of the cell culture remained exposed to the phorbol ester $(72 \mathrm{~h}$ and $96 \mathrm{~h}$ ) 
creases upon treatment of U937 cells with TPA. The mRNA concentration drastically rises at the third day of treatment (i.e. with a longer lag period than with the phospholipids described above). Washing the cells after $48 \mathrm{~h}$ of TPA treatment does not interfere with the induction process initiated by TPA, as the $\mathrm{H} 1^{\circ}$ mRNA concentration increases for the next 3 days. The $\mathrm{H} 1^{\mathrm{II}}$ subtype of H1 shows mRNA level changes as expected for a replication-dependent histone subspecies in decreasing upon addition of TPA. This gradual decrease of the H1 mRNA concentration reflects the inhibition of cell proliferation. Even washing the cells after $48 \mathrm{~h}$ does not interrupt this decay.

\section{Effects of phospholipids, alkylphospholines and phorbol ester on nitroblue tetrazolium reduction}

During the course of differentiation U937 cells change their pattern of membrane antigen expression towards a monocyte-like phenotype. This includes the acquisition of CD14 (Hass et al. 1989; Nona et al. 1989), CD11 (Hass et al. 1989; Cabanas et al. 1988) and HLA-DR antigen (Aranzana-Seisdedos et al. 1988; Testa et al. 1988). On the other hand, transferrin receptors (Hass et al. 1989; Sheta et al. 1988) and CD4 antigen (Faltynek et al. 1989; Larsson et al. 1988), as typical markers for early stages of the myeloic lineage, are reduced or lost.

Table 1 summarizes the influence of TPA, He-PC and ET-18- $\mathrm{OCH}_{3}$ on surface antigen expression. These compounds in general seem to have quite similar effects. They all enhance CD14 and CD11, whereas expression of CD4 antigen and transferrin receptor is diminished. There are, however, striking quantitative differences in antigen expression levels induced by these compounds. TPA, for instance, strongly enhances CD11, but has weak effects on CD14. In contrast, $\mathrm{He}-\mathrm{PC}$ and $\mathrm{ET}-18-\mathrm{OCH}_{3}$ primarily enhance CD14 and marginally change CD11 levels.

After TPA treatment U937 cells lose almost $85 \%$ of their CD4 antigens and about $50 \%$ of their transferrin receptors.

He-PC treatment elicits just small changes of both antigens while ET-18- $\mathrm{OCH}_{3}$ decreases transferrin receptors to about $15 \%$ of control values.

He- $\mathrm{PC}_{6}$ and ES-16-OH-treated cells show no significant difference of antigen expression pattern and quantity compared to control cell cultures.

Though HLA-DR induction and expression could have been expected during U937 differentiation (Aranzana-Seisdedos et al. 1988; Testa et al. 1988) we were unable to detect any membrane expression of this antigen. There is some evidence that the membrane transfer mechanism for cytoplasmatic HLA-DR proteins may be defective in some U937 cultures (Yunis et al. 1989).

\section{Effects of phospholipids, alkylphosphocholines and phorbol ester on nitroblue tetrazolium reduction}

Mature phagocytic cells, like macrophages and neutrophiles, are able to reduce nitroblue tetrazolium (Babior 1978). In leukemia U937 cells nitroblue tetrazolium re-

Table 1. Change of surface antigen expression on U937 after $48 \mathrm{~h}$ of exposure to TPA, He-PC, ET-18-OCH 3 , He-PC 6 , and ES-16-OH. Data represent mean fluorescence intensities determined by flow cytometry (mean of three independent experiments + SD)

\begin{tabular}{|c|c|c|c|c|c|}
\hline Incubation & $\begin{array}{l}\text { LeuM3 } \\
\text { (CD14) }\end{array}$ & $\begin{array}{l}\text { Mo2 } \\
\text { (CD14) }\end{array}$ & $\begin{array}{l}\text { Leu } 3 \\
\text { (CD4) }\end{array}$ & $\begin{array}{l}\text { Mo1 } \\
\text { (CD11) }\end{array}$ & $\begin{array}{l}\text { Transferrin } \\
\text { receptor }\end{array}$ \\
\hline Control & $4 \pm 3$ & $23 \pm 8$ & $304 \pm 21$ & $360 \pm 31$ & $268 \pm 5$ \\
\hline TPA $50 \mathrm{ng} / \mathrm{ml}$ & $6 \pm 2$ & $51 \pm 9$ & $46 \pm 11$ & $463 \pm 29$ & $137 \pm 11$ \\
\hline He-PC $10 \mu \mathrm{g} / \mathrm{ml}$ & $31 \pm 6$ & $111 \pm 18$ & $218 \pm 28$ & $397 \pm 20$ & $173 \pm 9$ \\
\hline $\mathrm{ET}-18-\mathrm{OCH}_{3} 5 \mu \mathrm{g} / \mathrm{ml}$ & $47 \pm 11$ & $127 \pm 10$ & $217 \pm 30$ & $385 \pm 37$ & $39 \pm 13$ \\
\hline $\mathrm{He}-\mathrm{PC}_{6} 10 \mu \mathrm{g} / \mathrm{ml}$ & $5 \pm 2$ & $3 \pm 1$ & $316 \pm 17$ & $352 \pm 10$ & $349 \pm 9$ \\
\hline ES-16-OH $10 \mu \mathrm{g} / \mathrm{ml}$ & 0 & $21 \pm 5$ & $333 \pm 20$ & $361 \pm 17$ & $344 \pm 13$ \\
\hline
\end{tabular}

Table 2. Nitroblue tetrazolium reduction capacity of U937 cells treated with TPA $(50 \mathrm{ng} / \mathrm{ml}), \mathrm{He}-\mathrm{PC}(5 \mu \mathrm{g} / \mathrm{ml})$, ET- $18-\mathrm{OCH}{ }_{3}$ $(2 \mu \mathrm{g} / \mathrm{ml}), \mathrm{He}^{-} \mathrm{PC}_{6}(10 \mu \mathrm{g} / \mathrm{ml})$ and $\mathrm{ES}-16-\mathrm{OH}(10 \mu \mathrm{g} / \mathrm{ml})$ for $48 \mathrm{~h}$. Cell viability under the used concentrations of compound were between 80 and $90 \%$

\begin{tabular}{lcc}
\hline Incubation & Positive cells $^{\mathrm{a}}(\%)$ & Formazan content $^{\mathbf{b}}(\%)$ \\
\hline Control & $1.6 \pm 0.6$ & 100 \\
$\mathrm{TPA} 50 \mathrm{ng} / \mathrm{ml}$ & $7.0 \pm 1.1$ & $131 \pm 10$ \\
$\mathrm{He}-\mathrm{PC} 5 \mu \mathrm{g} / \mathrm{ml}$ & $17.0 \pm 1.3$ & $173 \pm 11$ \\
$\mathrm{ET}-18-\mathrm{OCH}{ }_{3} 5 \mu \mathrm{g} / \mathrm{ml}$ & $13.8 \pm 1.6$ & $148 \pm 16$ \\
$\mathrm{He}-\mathrm{PC} \mathrm{C}_{6} 10 \mu \mathrm{g} / \mathrm{ml}$ & $1.0 \pm 0.6$ & $95 \pm 11$ \\
$\mathrm{ES}-16-\mathrm{OH} 10 \mu \mathrm{g} / \mathrm{ml}$ & $0.5 \pm 0.2$ & $94 \pm 12$
\end{tabular}

\footnotetext{
a Percentage of cells containing formazan deposits as counted in a Neubauer chamber

b Formazan content of cell lysates measured photometrically as percentage of control. Data represent mean of three independent experiments $\pm \mathrm{SD}$
} 
duction can be induced when cells become terminally differentiated (Geissler et al. 1989; Gavison et al. 1988). As shown in Table 2, TPA, He-PC and ET-18- $\mathrm{OCH}_{3}$ increase the number of formazan-positive cells five- to tenfold over control cell levels. In contrast, ES-16-OH and He- $\mathrm{PC}_{6}$ have no effect on formazan formation. This could be obtained by counting nitroblue-tetrazoliumpositive cells in a Neubauer chamber as well as by spectrophotometric measurement of formazan content in the supernatant of lysed cells.

\section{Discussion}

The human promonocytic leukemia cell line U937 is inducible towards macrophage differentiation upon addition of several substances, such as phorbol ester, lymphokines, retinoic acid or calcitriol (Gidlund et al. 1981; Koeffler et al. 1980; Koeffler 1983). We have treated U937 cells with hexadecylphosphocholine (He-PC) and 1-O-octadecyl-2-O-methyl-rac-glycero-3-phosphocholine $\left(\mathrm{ET}-18-\mathrm{OCH}_{3}\right)$, two lipids with well-known cytostatic and cytotoxic properties. These compounds were compared with phorbol ester and two other lipids lacking antiproliferative activity with respect to several parameters of growth inhibition and differentiation.

The $\mathrm{H} 1$ histone subtype $\mathrm{H} 1^{\circ}$ has been first described as a characteristic feature of the chromatin of non-dividing cells, as in adult liver (Panyim and Chalkley 1969; Gabrielli et al. 1985) or in a variety of cell lines upon inhibition of DNA replication (Zlatanova 1980; Chabanas et al. 1985; Pehrson and Cole 1980; Hall et al. 1985; Pieler et al. 1981). Exceptions to this apparent correlation between a repression of DNA synthesis and an induction of $\mathrm{H} 1^{\circ}$ gene expression have been described in the meantime in Ehrlich ascites tumor cells (Banchev et al. 1988; Bouterfa et al. 1990), in erythroleukemia cells (Keppel et al. 1977; Osborne and Chabanas 1984), in mouse teratocarcinoma cells (Alonso et al. 1988) and in developing tissues in vivo (Gjerset et al. 1982). The human hepatoma cell line $\mathrm{HepG} 2$, for example, expresses the $\mathrm{H}^{\circ}$ gene constitutively at a high level (Gabrielli et al. 1985; Hochhuth and Doenecke 1990), irrespective of the state of DNA replication (Hochhuth and Doenecke 1990).

An established system of induction of cell differentiation in leukemia cell lines is the macrophage type of development of TPA-treated U937 cells (Gidlund et al. 1981). We have shown that this tumor cell system reacts to phorbol ester treatment by changing three parameters: the proliferation rate decreases, the steady-state level of $\mathrm{H} 1^{\circ}$ mRNA increases and markers of macrophage-type differentiation are induced.

This correlation between an increase of the level of $\mathrm{H} 1^{\circ}$ and the differentiation of a particular cell type had been initially documented at the protein level in Friendvirus-transformed erythroleukemia cells (Keppel et al. 1977). In the meantime, Cheng and Skoultchy (1989) demonstrated a rapid induction of $\mathrm{H}^{\circ} \mathrm{mRNA}$ and a second $\mathrm{H} 1 \mathrm{mRNA}$ ( $1.8 \mathrm{~kb}$ in length) in mouse erythroleukemia cells. In that case, the induction of both mRNAs was negatively regulated by the DNA-binding c-myc protein. Lord et al. (1990) demonstrated in murine myeloid cells that an increased expression of the $\mathrm{H} 1^{\circ}$ gene is an intrinsic part of the immediate early response of these cells to terminal differentiation and to growth arrest stimuli. In that system, induction of myeloid cell differentiation did not just enhance the synthesis of $\mathrm{H} 1^{\circ}$, but the expression of a second (cell-cycle-independent) replacement histone gene (H3.3) was equally observed. An additional element of this early genetic response of myeloid cells was a stable induction of $j u n B$, a nuclear transcription factor. Thus, modulations in the structure of chromatin and direct effects on the transcription system parallel and precede individual steps of differentiation and growth arrest.

The antineoplastic lipids $\mathrm{He}-\mathrm{PC}$ and $\mathrm{ET}-18-\mathrm{OCH}_{3}$ induce an increased expression of the $\mathrm{H} 1^{\circ}$ gene $3-6 \mathrm{~h}$ after addition to the culture medium. This early accumulation of $\mathrm{H} 1^{\circ}$ mRNA parallels the inhibition of DNA replication caused by these compounds. Northern blot analysis of the same RNA preparations with probes for replication-dependent $\mathrm{H} 1$ and core histone subtypes shows the differential regulation of the replacement (Smith et al. 1984) histone $\mathrm{H} 1^{0}$ versus the replication-dependent histones, which decrease upon inhibition of DNA replication. TPA essentially causes the same changes as the antineoplastic phospholipids on $\mathrm{H} 1^{0}$ synthesis, but with a prolonged lag period.

By contrast, the two other lipids ES-16-OH and He$\mathrm{PC}_{6}$, which lack antitumoral activity, have no effect on cell proliferation, $\mathrm{H} 1^{\circ}$ gene expression and membrane antigen expression. It should be mentioned, however, that both compounds when compared to ET-18-OCH and $\mathrm{He}-\mathrm{PC}$, show very similar physical properties with respect to oil/water partition coefficients ( $\log p$ values), critical micelle concentrations and induction of hemolysis in human erythrocytes (Unger and Eibl 1990; Unger 1989). Thus, despite the similarity of physical properties of the four lipids, only the two compounds with antitumoral activity show the described biological effects in the U937 cell line. The results presented here indicate that the antineoplastic phospholipids provide a novel system to investigate this correlation. It has been shown before that both substances lead to an inhibition of growth (Berdel et al. 1981; Munder et al. 1981; Vehmeyer et al. 1989; Muschiol et al. 1987; Hilgard et al. 1988) and to an induction of differentiation (Honma et al. 1981; 1983; Hilgard et al. 1989). The induction of expression of the $\mathrm{H}^{\circ}{ }^{\circ}$ histone gene is a very early step, which precedes the expression of macrophage markers and parallels the antiproliferative action of the phospholipid compounds. It has been shown, on the other hand, that inhibition of replication and $\mathrm{H}^{\circ}$ induction are independent processes. Thus, we may conclude that the partial restructuring of chromatin, as indicated by the accumulation of $\mathrm{H}^{0}$, is one essential step contributing to the chain of events triggered by alkyllysophospholipids and alkylphosphocholines. 


\section{References}

Alonso A, Breuer B, Bouterfa H, Doenecke D (1988) Early increase in histone $\mathrm{H} 1^{\circ}$ mRNA during differentiation of $\mathrm{F} 9$ cells to parietal endoderm. EMBO J 7:3003-3008

Andreesen R, Giese V (1987) Differential effects of ether lipids on the activity and secretion of interleukin-1 and interleukin 2 . Lipids 22:836-841

Aranzana-Seisdedos F, Mogensen SC, Vuillier F, Fiers W, Virelizer JL (1988) Autocrine secretion of tumor necrosis factor under the influence of interferon-gamma amplifies HLA-DR gene induction in human monocytes. Proc Natl Acad Sci USA 85:6087-6091

Babior B (1978) Oxygen-dependent microbial killing by phagocytes. N Engl J Med 12:659-666

Banchev R, Srebreva L, Zlatanova J, Tsanev R (1988) Immunofluorescent localization of histone $\mathrm{H}^{\circ}$ in the nuclei of proliferating and differentiating Friend cells. Exp Cell Res 177:1-8

Berdel WE, Bausert WRE, Fink U, Rastetter J, Munder PG (1981) Anti-tumor action of alkyl-lysophospholipids. Anticancer Res $1: 345-352$

Bouterfa H, Doenecke D, Löffler M (1990) Increased level of histone $\mathrm{H} 1^{\circ}$ mRNA in hypoxic Ehrlich ascites tumor cells. Exp Cell Res 188:160-163

Cabanas S, Sanchez-Madrid F, Acevedo A, Bellon T, Fernandez JM, Larraga V, Bernabev C (1988) Characterization of a SD11reactive monoclonal antibody $(\mathrm{HC} 1 / 1)$ obtained by immunizing with phorbol ester differentiated U937 cells. Hybridoma 7:167176

Chabanas A, Khoury E, Goeltz P, Froussard P, Gjerset R, Dod B, Eisen H, Lawrence JJ (1985) Effects of butyric acid on cell cycle regulation and induction of histone $\mathrm{H} 1^{\circ}$ in mouse cells and tissue culture. J Mol Biol 183:141-151

Cheng G, Skoultchy AI (1989) Rapid induction of polyadenylated $\mathrm{H} 1$ histone mRNAs in mouse erythroleukemia cells is regulated by c-myc. Mol Cell Biol 9:2332-2340

Chirgwin J, Przybyla A, MacDonald R, Rutter W (1979) Isolation of biologically active ribonucleic acid from sources enriched in ribonuclease. Biochemistry 18:5294-5299

D'Anna JA, Gurley LR, Tobey RA (1982) Synthesis and modulations in the chromatin contents of histones $\mathrm{H}^{\circ}{ }^{\circ}$ and $\mathrm{H} 1$ during $\mathrm{G}_{1}$ and $\mathrm{S}$ phases in chinese hamster cells. Biochemistry 21:39914001

D'Incalci M, Allavena P, Wu RS, Bonner WM (1986) H1 variant synthesis in proliferating and quiescent human cells. Eur J Biochem 154:273-279

Doenecke D, Tönjes R (1986) Differential distribution of lysine and arginine residues in the closely related histones $\mathrm{H} 1^{\circ}$ and $\mathrm{H} 5 . \mathrm{J}$ Mol Biol 187:461-464

Eibl H (1981) Synthesis of phospholipids. In: Knight CG (ed) Liposomes, from physical structure to therapeutic application. E1sevier, Amsterdam, pp 19-50

Eick S, Nicolai M, Mumberg D, Doenecke D (1989) Human H1 histones: conserved and varied sequence elements in two $\mathrm{H} 1 \mathrm{sub}-$ type genes. Eur J Cell Biol 49:110-115

Faltynek CR, Finch LR, Miller P, Overton WR (1989) Treatment with recombinant IFN-gamma decreases cell surface CD4 levels on peripheral blood monocytes and on myelomonocyte cell lines. J Immunol 142:500-508

Gabrielli F, Aden D, Carrel SC, von Bahr C, Rane A, Angeletti CA, Hancock R (1985) Histone complements of human tissues, carcinomas and carcinoma derived cell lines. Mol Cell Biochem 65:57-66

Gavison R, Matzner Y, Fibach E (1988) Differential induction of monocytic functions by dibutyryl cyclic AMP and retinoic acid in a human monoblast cell line U937. Isr J Med Sci 24:697701

Geissler K, Harrington M, Srivastava C, Leemhuis T, Tricot G, Broxmeyer HE (1989) Effects of recombinant human colony stimulating factor (CSF) (granulocyte-macrophage CSF, granulocyte CSF and CSF-a) on human monocyte/macrophage differentiation. J Immunol 143:140-146
Gidlund M, Orn A, Pattengale PK, Jansson M, Wigzell H, Nilsson K (1981) Natural killer cells kill tumor cells at a given stage of differentiation. Nature 292:848-850

Gjerset R, Gorka C, Hasthorpe S, Lawrence JJ, Eisen H (1982) Developmental and hormonal regulation of protein $\mathrm{H}^{\circ}$ in rodents. Proc Natl Acad Sci USA 79:2333-2337

Hall JM, Davis C, Cole RD (1985) Induction of $\mathrm{H} 1^{\circ}$ differs with different treatments among different cell lines. FEBS Lett 189:9296

Hass R, Bartels H, Topley N, Hadam M, Köhler L, Goppelt-Strube M, Resch K (1989) TPA induced differentiation and adhesion of U937 cells: changes in ultrastructure, cytoskeletal organization and expression of cell surface antigens. Eur J Cell Biol 48:282-293

Hilgard P, Stekar J, Vögeli H, Engel J, Schumacher W, Eibl H, Unger C, Berger MR (1988) Characterization of the antitumor activity of hexadecylphosphocholine (D 18506). Eur J Cancer Res Clin Oncol 24:1457-1461

Hilgard P, Harlemann JH, Voegeli R, Maurer HR, Echarti C, Unger C (1989) The antineoplastic activity of hexadecylphosphocholine (HPC) is associated with tumor cell differentiation. Proc Am Assoc Cancer Res 30:2310

Hochhuth C, Doenecke D (1990) The expression of the histone $\mathrm{H} 1^{\circ}$ gene in the human hepatoma cell line $\mathrm{HepG} 2^{0}$ is independent from the state of cell proliferation. Differentiation 43:212-219

Honma Y, Kasukabe T, Okabe-Kado J, Hozumi M, Tusushima S, Nomura H (1981) Induction of differentiation of cultured human and mouse myeloid cells by alkyllysophospholipids. Cancer Res 41:3211-3216

Honma Y, Kasukabe T, Okabe-Kado J, Hozumi M, Tusushima S, Nomura H (1983) Antileukemic effect of alkylphospholipids. I. Inhibition of proliferation and induction of differentiation of cultured myeloid leukemia cells by alkylethyleneglycophospholipids. Cancer Chemother Pharmacol 11:73

Keppel F, Allet B, Eisen H (1977) Appearance of a chromatin protein during the erythroid differentiation of Friend virus transformed cells. Proc Natl Acad Sci USA 74:653-656

Koeffler PH (1983) Induction of differentiation of human acute myelogenous leukemia cells: therapeutic implications. Blood 62:709-721

Koeffler HP, Bar-Eli M, Territo M (1980) Phorbol diester induced macrophage differentiation of leukemic blasts from patients with myelogenous leukemia. J Clin Invest 66:1101-1104

Kress H, Tönjes R, Doenecke D (1986) Butyrate induced accumulation of a $2.3 \mathrm{~kb}$ polyadenylated $\mathrm{H} 1^{\circ}$ histone mRNA in HeLa cells. Nucleic Acids Res 14:7189-7197

Larsson LG, Ivhed I, Gidlund M, Pettersson R, Vennström B, Nilsson K (1988) Phorbol ester-induced terminal differentiation is inhibited in human U-937 monoblastic cells expressing a vmyc oncogene. Proc Natl Acad Sci USA 85:2638-2642

Lord KA, Hoffmann-Liebermann B, Liebermann DA (1990) Complexity of the immediate early response of myeloid cells to terminal differentiation and growth arrest includes ICAM-1, Jun$\mathrm{B}$ and histone variants. Oncogene 5:387-396

McMaster GH, Carmichael GG (1977) Analysis of single and double stranded nucleic acids on polyacrylamide and agarose gels by using glyoxal and acridine orange. Proc Natl Acad Sci USA $74: 48354838$

Munder PG, Weltzien HU, Modolell M (1976) Immunopathology. In: Miescher PA (ed) VIIth International Symposium on Immunopathology. Schwabe, Basel, pp 411-424

Munder PG, Modolell M, Bausert W, Oettgen HF, Westphal O (1981) Alkyl-lysophospholipids in cancer therapy. In: Hersh EM, Chirigos MA, Mastrangelo MJ (eds) Augmenting agents in cancer therapy. Raven, New York, pp 441-458

Muschiol C, Berger MR, Schuler B, Scherf HE, Garzon FT, Zeller WJ, Unger C, Eibl H, Schmähl D (1987) Alkylphosphocholines: toxicity and anticancer properties. Lipids 22:930-934

Noma T, Nakakubo H, Hama K, Honjo T (1989) Multiple effects of human recombinant interleukin 4 on human myeloid monocyte cell lines. Immunol Lett 21:323-328 
Osborne HB, Chabanas A (1984) Kinetics of histone $\mathrm{H} 1^{\circ}$ accumulation and commitment to differentiation in murine erythroleukemia cells. Exp Cell Res 152:449-458

Panyim S, Chalkley RG (1969) A new histone found only in mammalian tissue with little cell division. Biochem Biophys Res Commun 37:1042-1049

Pehrson J, Cole RD (1980) Histone $\mathrm{H} 1^{\circ}$ accumulates in growth inhibited cultured cells. Nature 285:43-45

Pieler C, Adolf GR, Swetly P (1981) Accumulation of histone $\mathrm{H}^{\circ}{ }^{\circ}$ during chemically induced differentiation of murine neuroblastoma cells. Eur J Biochem 115:329-333

Pina B, Suau P (1987) Changes in the proportions of histone $\mathrm{H} 1^{\circ}$ subtypes in brain cortical neurons. FEBS Lett 210:161-164

Pina B, Martinez P, Simon L, Suau P (1984) Differential kinetics of histone $\mathrm{H} 1^{\circ}$ accumulation in neuronal and glial cells from rat cerebral cortex during postnatal development. Biochem Biophys Res Commun 123:697--702

Ralph P, Harris PE, Punjabi CJ, Welte K, Litcofsky PB, Ho MK, Rubin BY, Moore MAS, Springer TA (1983) Lymphokine inducing "terminal differentiation" of the human monoblast leukemia line U937. A role for interferon-gamma. Blood 62:1169

Rigby P, Dieckmann M, Rhodes C, Berg P (1977) Labeling deoxyribonucleic acid to high specific activity in vitro by nick translation with DNA polymerase I. J Mol Biol 113:237-251

Sheta B, Dransfield I, Partridge LF, Barker MD, Burton DR (1988) Dibutyryl cyclic AMP stimulation of a monocyte-like cell line, U937: a model for monocyte chemotaxis and Fc-receptor-related functions. Immunology 63:483-490

Smith BJ, Harris MR, Sigournay CM, Mayes ELV, Bustin M (1984) A survey of $\mathrm{H}^{\circ}{ }^{\circ}$ and $\mathrm{H} 5$-like protein structures and distribution in higher and lower eukaryotes. Eur J Biochem 138:309-317
Sundström C, Nilsson K (1976) Establishment and characterization of a human histiocyte lymphoma cell line (U937). Int J Cancer 17:565-577

Testa U, Ferbus D, Gabbianelli M, Boccoli G, Louache F, Thang MN (1988) Effect of endogenous and exogenous interferons on the differentiation of human monocyte cell line U937. Cancer Res 48:82-88

Trinchieri G, Kobayashi M, Rosen M, Loudön R, Murphy M, Perussia B (1986) Tumor necrosis factor and lymphotoxin induce differentiation of human myeloid cell lines in synergy with immune interferon. J Exp Med 164:1206-1225

Unger C (1989) Alkylphosphocholine und Analoga. Entwicklung einer neuen Substanzgruppe mit antineoplastischer Wirkung. Thieme, Stuttgart, S 1-106

Unger C, Eibl H (1990) Hexadecylphosphocholine: preclinical and first clinical results of a new antitumor drug. Lipids (in press)

van Helden $\mathrm{PD}$ (1985) Histone $\mathrm{H} 1^{0}$ : a maintainer of the differentiated cell state? Int J Biochem 17:381-385

Vehmeyer K, Kim DJ, Nagel GA, Eibl H, Unger C (1989) Effect of ether lipids on mouse granulocyte-macrophage progenitor cells. Cancer Chemother Pharmacol 24:58 60

Ways DK, Dodd RC, Bennett TE, Hooker JL, Earp HS (1988) Effect of retinoic acid on phorbol ester-stimulated differentiation and protein kinase c-dependent phosphorylation in the U937 human monoblastoid cell. Cancer Res 48:5779-5787

Yunis J, Band H, Bonneville F, Yunis EJ (1989) Differential expression of MHC class II antigens in myelomonocytic leukemia cell lines. Blood 73:931-937

Zlatanova JS (1980) Synthesis of histone $\mathrm{H}^{\circ}{ }^{\circ}$ is not inhibited in hydroxyurea treated Friend cells. FEBS Lett 112:199-202 